\title{
VITRINITE REFLECTANCE STUDIES OF COALS AND DISPERSED ORGANIC MATTER IN TERTIARY DEPOSITS IN THE ADVENT- DALEN AREA, SVALBARD
}

\begin{abstract}
Throndsen, T., 1982: Vitrinite reflectance studies of coals and dispersed organic matter in Tertiary deposits in the Adventdalen area, Svalbard. Polar Research 2:77-91.

Vitrinite reflectance measurements on coals and dispersed organic matter in Tertiary deposits in the Adventdalen area show that there is a continuous rank increase from 'sub-bituminous C' $(\mathrm{Ro}=0.40)$ at the top through $950 \mathrm{~m}$ to 'high volatile bituminous $B$ ' $(\mathrm{Ro}=0.70)$ at the base. Rank of the economically important coal horizon at the base of the Tertiary shows regional variation ranging from 'sub-bituminous $B$ ' $\left(R_{0}=0.41\right)$ to 'high volatile bituminous $A-B$ ' $\left(R_{0}=0.78\right)$. It is concluded that $1.0-1.5 \mathrm{~km}$ of Tertiary deposits were eroded during the postorogene uplift of Svalbard, and the area of greatest sediment accumulation migrated eastwards during deposition.

Torbjorn Throndsen, Saga Petroleum a.s., P.O. Box 550, N-1301 Sandvika, Norway.
\end{abstract}

\section{Introduction}

A recent regional study of coal rank along the base of the Tertiary sequence in Spitsbergen (Manum and Throndsen 1978) revealed a rather abrupt decrease in rank level east and northeastwards within the Adventdalen area. The present paper gives a detailed description of the rank level using vitrinite reflectance, along the base of the Tertiary in this area, and forms thereby a local improvement and updating of the more regional work mentioned above. Geological implications of vertical and lateral rank variations are discussed. 


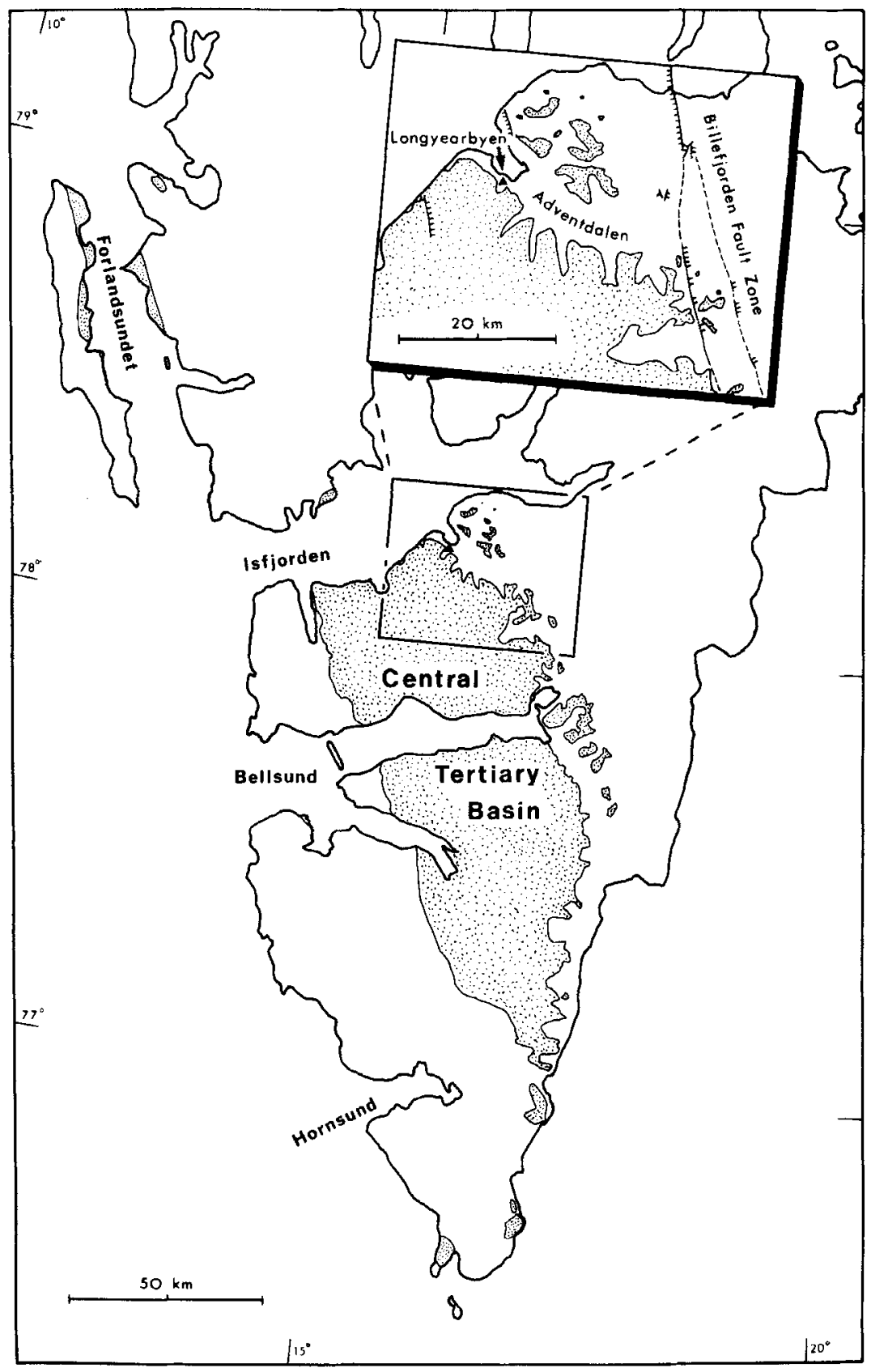

Fig. 1 Map of southern Spitsbergen showing Tertiary deposits. 


\section{Geological background}

The geology of the Central Tertiary Basin in Spitsbergen (Fig. 1) has been the subject of several comprehensive studies during the last two decades (ATKINSON 1963, LIVSIC 1965 and 1974, VONDERBANK 1970, BIRKENMAJER 1972, MAJOR and NAGY 1972, KELLOGG 1975, HARLAND et al. 1976, MANUM and THRONDSEN 1978, STEEL et al. 1979). Here only a brief summary as pertinent to the present study is given.

More than $2300 \mathrm{~m}$ of Tertiary sediments are still preserved in central parts of the basin (HARLAND et al. 1976). The succession consists of alternating shales, siltstones and sandstones of deltaic origin. Coal seams occur close to the base (Firkanten Fm.) and in the uppermost part (Aspelintoppen Fm.). Fig. 2 outlines the stratigraphy. A suggestion as to the age has to be based on a few dated horizons which strongly suggest a Paleocene-Eocene age for the entire sequence (MANUM and THRONDSEN 1978).

The sediment accumulation pattern appears to be controlled by the growth of the Tertiary Fold Belt along the west coast of Spitsbergen during the early opening of the Norwegian-Greenland Sea (KELLOGG 1975, MANUM and THRONDSEN 1978, STEEL et al. 1979). Only milder effects of Tertiary deformation are known further east where tectonic activity was largely restricted to a series of north-south trending lineaments. The most prominent of these is the Billefjorden Fault Zone which forms the eastern limb of the Central Tertiary Basin.

The area covered by the present study is located on the northeastern flank of the basin (Figs. 1, 3). More than $1000 \mathrm{~m}$ of Tertiary sediments are still preserved in southwestern parts of this area. To the east and northeast, however, the sequence is deeply eroded and only the lower units are preserved. Only a few minor outcrops are preserved upon the ridge of the Billefjorden Fault Zone and no one east of it.

\section{Rank Studies}

The coal measures in the lower part of the Firkanten Formation, the Todalen Member (STEEL et al. 1979), crop out extensively in the Adventdalen area. They have been subjected to mining activity during most of this century and so far they have been the most important economic resource in Svalbard. In spite of this interest, surprisingly little information is available on their rank and petrographic composition. HORN (1928) used KOH-tests and bulk chemical analyses for his rank determinations. He found coals from Adventtoppen (Fig. 3, St. 1) to be 


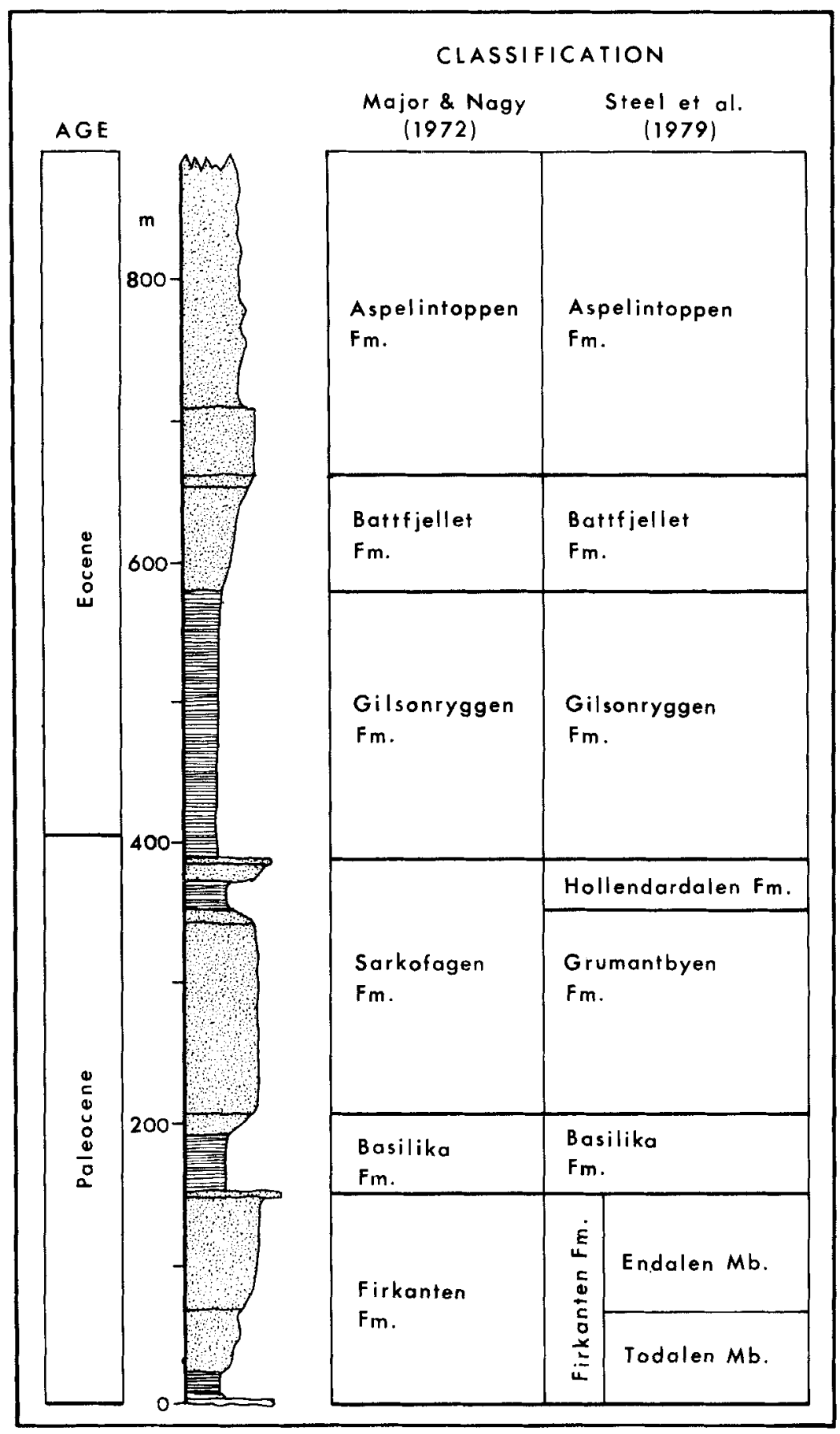

Fig. 2 Lithostratigraphic nomenclature and age of the Tertiary sequence in the Central Tertiary Basin. 
'Glanzbraunkohle' (DIN-classification, Fig. 4), while coals from Longyearbyen (Fig. 3, St. 21) were classified as 'Gasflammkohle'. HOFFMAN and HOEHNE (1959) found a volatile yield of $42.5 \%$ in coals from Longyearbyen which is in agreement with HORN's data. The most comprehensive study to now was by MANUM and THRONDSEN (1978) who used vitrinite reflectance for their rank determinations. Their observations are consistent with the results cited above, although in addition they document considerable lateral rank variation throughout the Tertiary basin.

The present study is based on vitrinite reflectance analysis on material collected during various expeditions organized by the Norsk Polarinstitutt and by the Institute of Geology and the Paleontological Museum at the University of Oslo. 27 stations with a wide distribution within the Adventdalen area have been sampled (Fig. 3). Most of the samples, both coals and clastic lithologies, are hand specimens collected in situ in surface exposures, some are hand collected inside mines, while samples

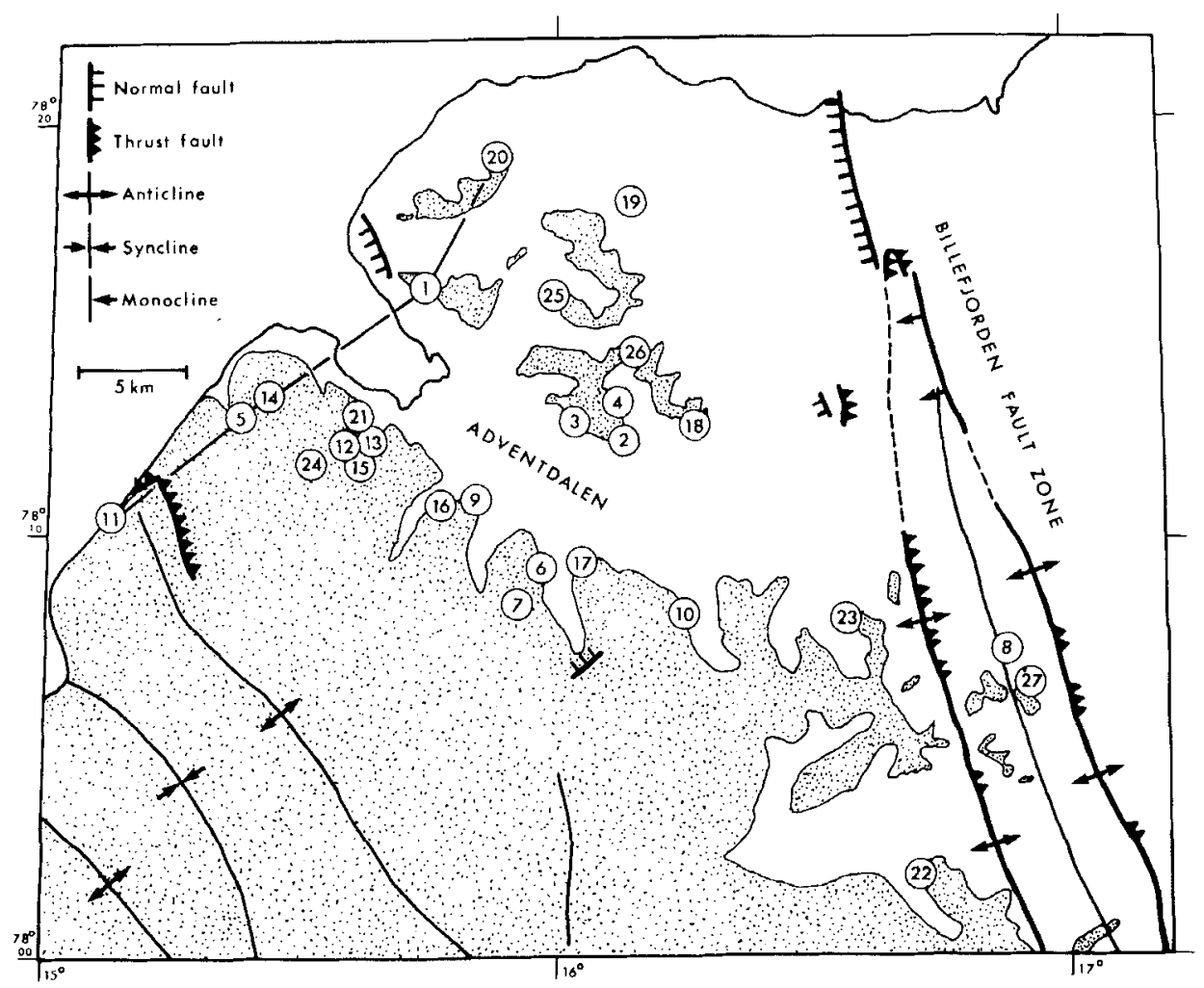

Fig. 3 Map of the Adventdalen area showing Tertiary deposits, structural elements, and sample localities (indicated by numbers). 


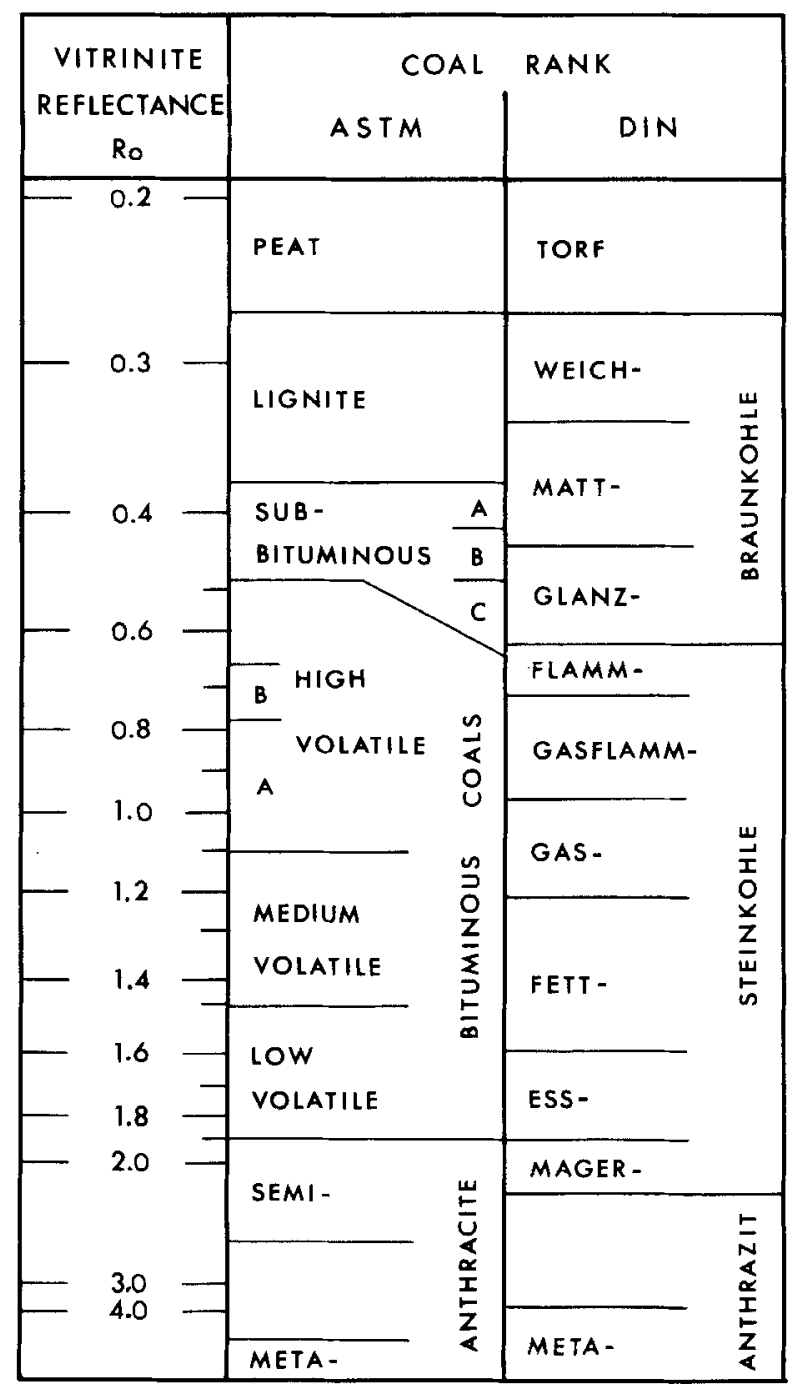

Fig. 4. Coal ranks according to the German (DIN) and U.S. (ASTM) rank classification and vitrinite reflectance values.

from Bjørndalen (Fig. 3, St. 5) are from cores. Sample processing, equipment, techniques, and data evaluation procedures are as described by MANUM and THRONDSEN (1978). 


\section{Rank patterns and geological implications}

Rank increase with depth has been established in two sections through the Tertiary sequence: at Carl Lundhfjellet and Nordenskiöldfjellet (Fig. 3, Sts. 7, 24). Both coals and clastic samples are included to obtain sufficient data coverage. Fig. 5 is a plot of vitrinite reflectance against depth (linear scale). The two sections are plotted on the same diagram using the base of the Tertiary as a reference level. The curve drawn through the profile refers to the Nordenskiöldfjellet section and is weighted towards the good quality data. The vitrinite reflectance increases with depth from $R_{0}=0.40$ at the top, to Ro $=0.70$ at the base $950 \mathrm{~m}$ below, corresponding to the rank interval 'sub-bituminous $C$ ' to 'high volatile bituminous B' (ASTM classification, Fig. 4). The rank increase is believed to be continuous throughout the profile. The data from the Carl Lundhfjellet section indicate quite a similar interval and increase with depth.

A method of estimating the maximum depth of burial from vertical variation has been presented by DOW (1977). He stated that in a continuously subsiding basin a rank profile, based on vitrinite reflectance will approach a straight line, the maturation gradient, if vitrinite reflectance is plotted on a logarithmic scale and depth on a linear scale. By projecting the maturation gradient to Ro $=0.2$, which is believed to be the minimum value close to the surface, a rough estimate may be obtained on the maximum depth of burial. A semilogarithmic plot of the Nordenskiöldfjellet profile is shown in Fig. 6. A projection of the maturation gradient to the Ro $=0.2$ value implies that approximately $1250 \mathrm{~m}$ have been eroded at this station during the postorogene uplift of Svalbard. A similar estimate is obtained by a method proposed by HACQUEBARD (1977).

The coal-bearing part of the Firkanten Formation, the Todalen Member, is used as a reference horizon in the lateral description of the rank pattern. This basal unit of the Tertiary is excellent for a lateral rank study. Its thickness is less than $75 \mathrm{~m}$ within the investigated area and the coals offer a favourable material for vitrinite reflectance analysis. The Todalen Member has been sampled at 25 stations (Fig. 3). Fig. 7 outlines the resulting rank pattern, where each point has been obtained from at least two, and normally three, samples. The pattern is characterized by an overall decrease in rank level east and northeastwards. The only deviation is the values recorded at Knorringfjellet (Fig. 3, St. 19) which fall outside the general trend. The highest value recorded is $\mathrm{Ro}=0.78$ at Grumantbyen (Fig. 3, St. 11) corresponding to a 'high volatile bituminous A-B' rank. The lowermost values are observed in the Konusen Stäket area (Fig. 3, Sts. 1, 20, 25) with values as low as Ro $=0.4-0.5$, 


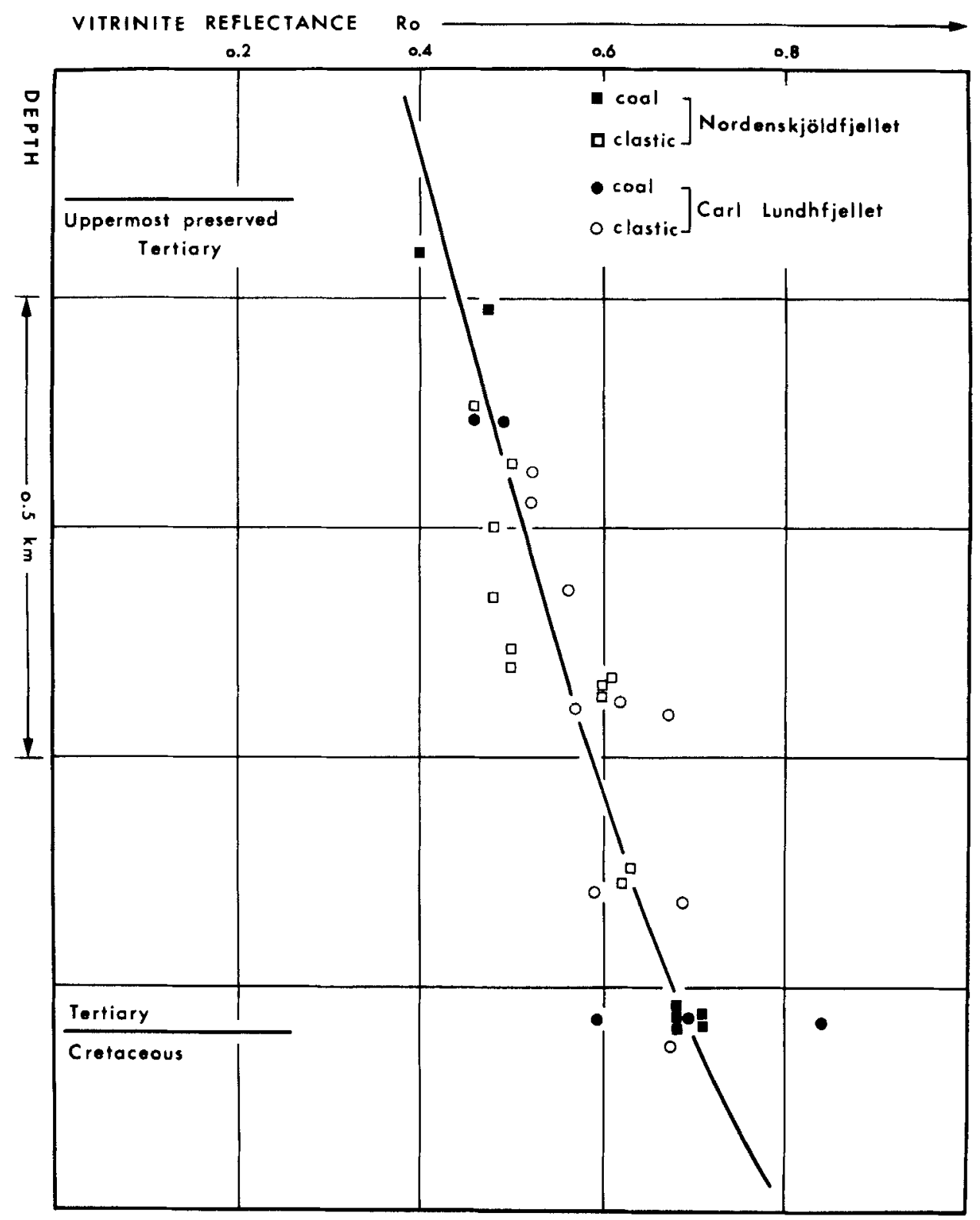

Fig. 5 Linear plot of vitrinite reflectance versus depth through the Tertiary sequence at Carl Lundhfjellet and Nordenskiöldfjellet. The uppermost preserved Tertiary refers to the Nordenskiöldfjellet section. 


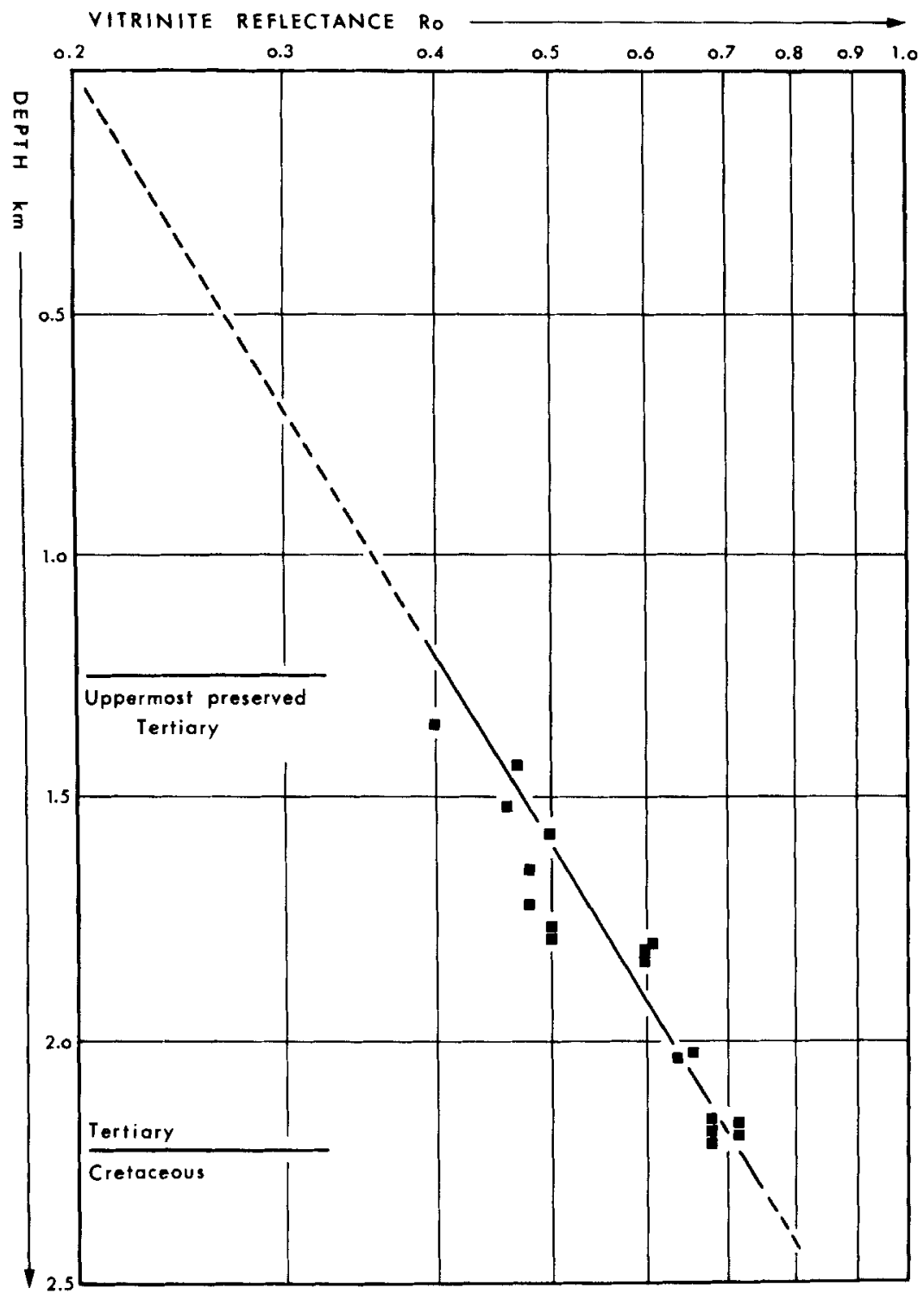

Fig. 6 Semilogarithmic plot of vitrinite reflectance versus depth through the Tertiary sequence at Nordenskiöldfjellet to establish a maturation gradient. Total depth of burial is obtained by extrapolating the gradient line to the Ro $=0.2$. 
indicating a 'sub-bituminous B-C' rank. The coals subjected to mining in various areas in Adventdalen are all of 'high volatile bituminous B' rank $($ Ro $=0.68-0.72)$.

As a first assumption we may regard the rank increase, or maturation gradient, established at Nordenskiöldfjellet as constant throughout the investigated area. This assumption is supported by data from Carl Lundhfjellet and from the Mesozoic in northeastern parts of the area (EIEN 1979, THRONDSEN 1979). This implies that the regional rank pattern should be attributed to a corresponding pattern of maximum depth of burial of the reference horizon. An isopach map (Fig. 8) indicating maximum depth of burial is constructed by combining the isoreflectance map (Fig. 7) and the maturation gradient (Fig. 6). The map is contoured at $500 \mathrm{~m}$ intervals. The rapid eastward thinning is notable: maximum thickness of the Tertiary sequence drops $750-1000 \mathrm{~m}$ within

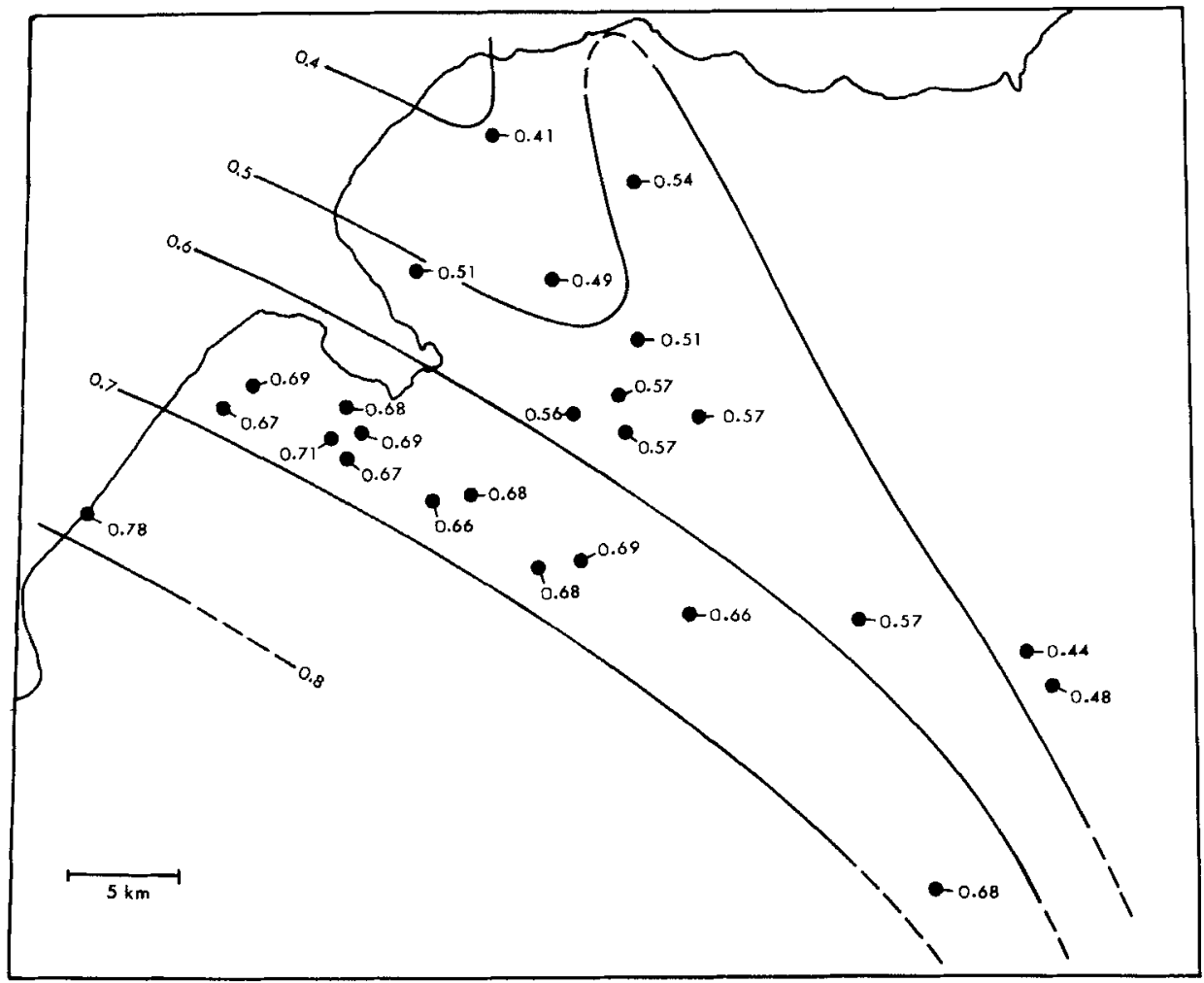

Fig. 7 Isorank map of the coal-bearing part of the Firkanten Formation (Todalen Member). Isoranks are contoured at 0.1 Ro intervals. The spot values indicate averages of all samples from any one locality. 
less than $15 \mathrm{~km}$ distance. An estimated overburden of $1250-1500 \mathrm{~m}$ at the easternmost stations suggests that the Tertiary depositional basin had a considerable eastward extent beyond the present outline of the basin. This suggestion is also supported by data obtained from the Mesozoic; vitrinite reflectance values recorded in Mesozoic strata at the easternmost Tertiary stations are similar to values recorded in corresponding strata further east. It is notable that the isopachs do not run parallel to the most prominent structural feature of the area, the Billefjorden Fault Zone, but appear to close up against it from a northwestern direction, i.e. the direction of Adventdalen and parallel it southwards from the Drönbreen - Tronfjellet area (Fig. 3, Sts. 8, 27) (cp. MANUM and THRONDSEN 1978). This pattern suggests that the Billefjorden Fault Zone and a zone of differential subsidence along Adventdalen were the main struc-

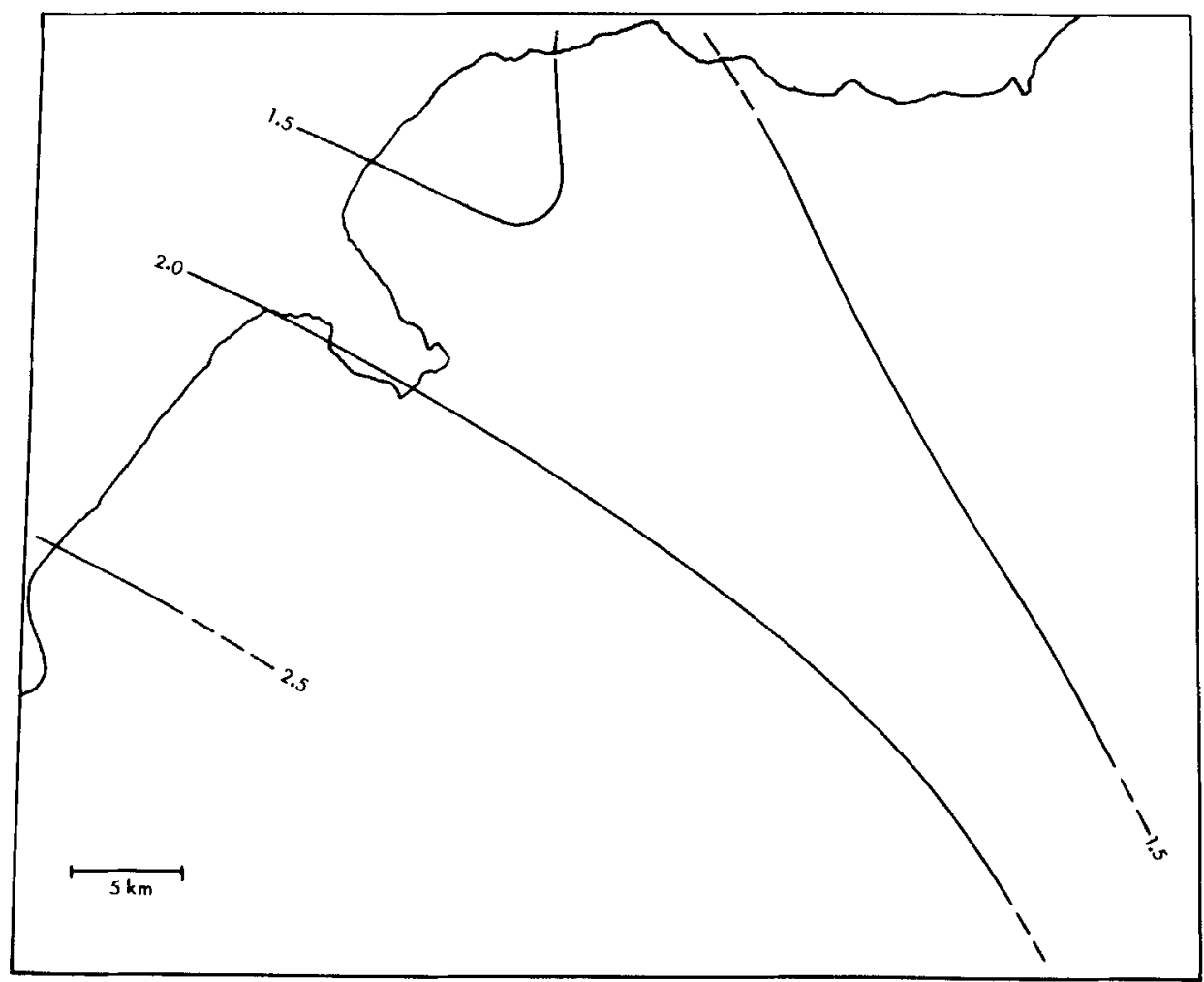

Fig. 8 Isopach map of maximum depth of burial of the coal-bearing part of the Firkanten Formation (Todalen Member), as inferred from vitrinite reflectance data. Isopachs are contoured at $0.5 \mathrm{~km}$ intervals. 

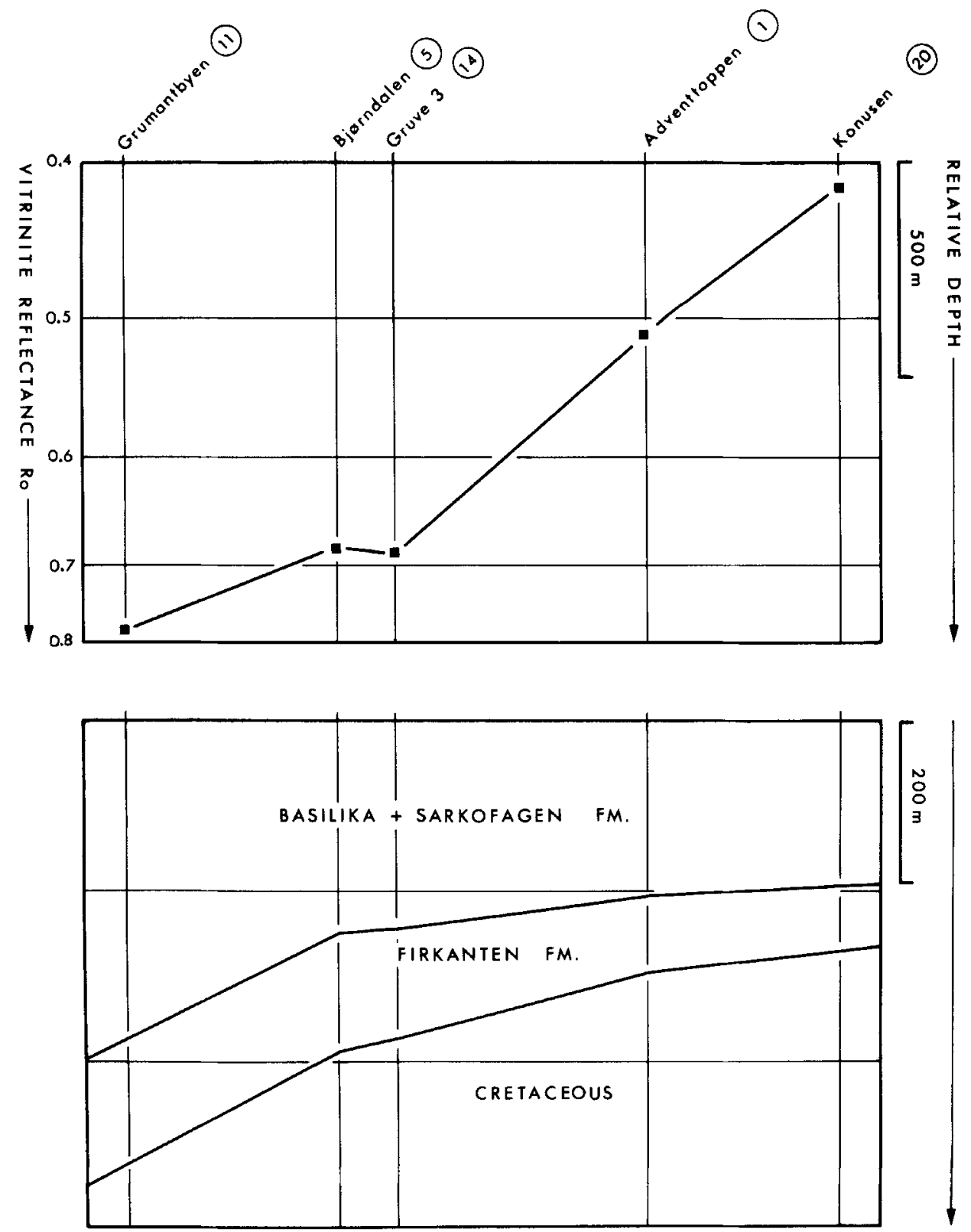

Fig. 9 Cross section comparing thicknesses of the three lowermost Tertiary formations and rank of the coal-bearing part of the Firkanten Formation (Todalen Member). The section is located in Fig. 3. Thickness data from VONDERBANK (1970) and KELLOGG (1975). 
tural elements of the area active during deposition of the Tertiary sequence. This is further illustrated in a section across the northern part of Adventdalen (Fig. 9) where vitrinite reflectance is plotted on a scale to indicate depth of burial on a linear scale. It demonstrates that the most abrupt eastward decrease occurs across Adventdalen (between St. 1 and St. 14). A zone of differential subsidence across Adventdalen was also suggested from detailed sedimentological studies by STEEL et al. (1979) who documented considerable thickness change within the Todalen Member. They suggested a growth fault along Adventdalen to explain this.

Fig. 9 also compares variations in total thickness of the three lowermost Tertiary formations (data from VONDERBANK 1,970 and KELLOGG 1975 ) with vitrinite reflectance data. In the direction of increasing vitrinite reflectance there is a corresponding increase in total thickness of the stratigraphic units. However, the abrupt increase in vitrinite reflectance across Adventdalen is reflected by only a slight thickening of this sequence. It shows, on the other hand, a pronounced increase in thickness further west. This lack of correspondence between vitrinite reflectance as an indicator of depth of burial and the total thickness of the three lowermost Tertiary formations suggests that the basin configuration changed during deposition of the Tertiary sequence. The area of greatest sedimentation migrated eastwards during deposition. A similar change in the subsidence pattern was also suggested by KELLOGG (1975) and by MANUM and THRONDSEN (1978) from more regional studies. The latter concluded that the area of greatest sediment accumulation migrated eastwards due to tectonic activity in the Tertiary Fold Belt starting in the uppermost Paleocene at the boundary between the Sarkofagen and Gilsonryggen Formations. This tectonic activity was probably accompanied by increased activity along major structural lineaments causing differential subsidence patterns as demonstrated across Adventdalen.

\section{Summary}

Rank profiles through the Tertiary sequence at Carl Lundhfjellet and Nordenskiöldfjellet show gradual rank increase from 'sub-bituminous $C^{\prime}($ Ro $=0.40)$ at the top to 'high volatile bituminous B' $\left(\mathrm{Ro}_{0}=0.70\right)$ at the base $950 \mathrm{~m}$ below. The profile at Nordenskiöldfjellet is used to establish a maturation gradient from which the maximum depth of burial for the base of the Tertiary at this locality is estimated at $2200 \mathrm{~m}$, implying that roughly $1250 \mathrm{~m}$ of sediments have been eroded.

Rank in the economically important coal measures at the base of the Tertiary sequence shows regional variation characterized by an over- 
all decrease in rank east and northeastwards, from a maximum of 'high volatile bituminous $\mathrm{A}-\mathrm{B}$ ' ( $\mathrm{Ro}=0.78)$ to a minimum of 'sub-bituminous $B-C^{\prime}($ Ro $=0.41)$. The coals subjected to mining in the Adventdalen area are all of 'high volatile bituminous B' rank ( Ro $=0.68-0.72$ ).

The rank data are interpreted in terms of maximum depth of burial. A notable eastward thinning of the sequence is evident. Maximum thickness of the sequence drops $750-1000 \mathrm{~m}$ within less than $14 \mathrm{~km}$ distance. An estimated overburden of $1250-1500 \mathrm{~m}$ at the easternmost station and data from the underlying Mesozoic suggests that the Tertiary depositional basin had a considerable eastward extent beyond its present limits. The most abrupt eastward decrease occurs across Adventdalen. This trend, however, is reflected by only a slight decrease in total thickness of the three lowermost formations. This sequence shows an abrupt decrease some distance to the west. This lack of correspondence suggests that the area of greatest sediment accumulation migrated eastwards during deposition, probably due to tectonic activity in the Tertiary fold belt, with the site of Adventdalen acting as a zone of great differential subsidence. The isopach pattern indicates that the Billefjorden Fault Zone and the zone of differential subsidence along the Adventdalen were the main structural elements active during deposition of the Tertiary sequence.

\section{Acknowledgements}

Thanks are due to TOR BJ RKE and SVEIN B. MANUM, the University of Oslo, and HARALD MAJOR, Norsk Polarinstitutt, for fruitful discussions of problems related to the rank study. MAJOR also provided many of the samples. I am grateful to ALV ORHEIM, Store Norske Spitsbergen Kulkompani A/S, for logistic assistance, permission for sampling inside the mines, and for some of the samples. LEENA $M$. KLAVENES and LARS KIRKSATHER have kindly and carefully prepared the samples.

The study was carried out at the Institute of Geology at the University of Oslo. It forms part of a research project on the genesis and alteration of Tertiary coals in Svalbard financed by the Norwegian Research Council for Science and the Humanities (NAVF). 


\section{References}

ATKINSON, D.J., 1963: Tertiary rocks of Spitsbergen. Amer.Ass. Petr. Geol. Bull. 47:302-323.

BIRKENMAJER, K., 1972: Tertiary history of Spitsbergen and continental drift. Acta Geol. Polonica 22:193-218.

DOW, W.G., 1977: Kerogen studies and geological interpretations. J. Geochem. Explor. 7(1977):79-99.

EIEN, M., 1979: Sammensetning og termisk omdannelse av organisk materiale i Spitsbergens underkritt. Cand. real.thesis, Univ. Oslo. $134 \mathrm{pp}$.

HACQUEBARD, P.A., 1977: Rank of coal as an index of organic metamorphism for oil and gas in Alberta. Geol. Surv. Can. Bull. 262:11-22.

HARLAND, W.B., C.A.G. PICKTON, and N.J.R. WRIGHT, 1976: Some coalbearing strata in Svalbard. Norsk Polarinstitutt Skrifter Nr. 164:7-28.

HOFFMANN, H. and K. HOEHNE, 1959: Untersuchungen an Steinkohlen der Kreideund Tertiärformation. I. Petrographische Eigenschaften. Brennst. -Chem. 4(40): 129-136.

HORN, G., 1928: Beiträge zur Kenntnis der Kohle von Svalbard (Spitsbergen und der Bäreninsel). Skr. om Svalbard og Ishavet Nr. 17:60 pp.

KELLOGG, H.E., 1975: Tertiary stratigraphy and tectonism in Svalbard and continental drift. Amer. Ass. Petr. Geol. Bull. 59(3):465-485.

LIVSIC, J.J., 1965: Paleogene deposits of Nordenskiöld Land, Vestspitsbergen. Materialy po geologii Spicbergena, Inst. Geol. Arktiki, Leningrad. English translation by J.E. Bradley, 1970: Geology of Spitsbergen 1965(2):193-215. National Lending Library for Science and Technology, Boston Spa.

-- 1974: Palaeogene deposits and the platform structure of Svalbard. Norsk Polarinstitutt Skrifter Nr. 159. 51 pp.

MAJOR, H. and J. NAGY, 1972: Geology of the Adventdalen map area. Norsk Polarinstitutt Skrifter Nr. $138.58 \mathrm{pp}$.

MANUM, S.B. and T. THRONDSEN, 1978: Rank of coal and dispersed organic matter and its geological bearing in the Spitsbergen Tertiary. Norsk Polarinstitutt Arbok 1977:159-177.

STEEL, R., A. DALLAND, and K. KALGRAFF, 1979: An outline of the history of sedimentation of Svalbard's Central Tertiary Basin. In: Norwegian Sea Symposium, Tromse. Norwegian Petroleum Society NSS/24:1-29.

THRONDSEN, T., 1979: Kerogen maturation of Triassic deposits in Svalbard. In: Norwegian Sea Symposium, Tromsø. Norwegian Petroleum Society NSS/28: 1-14.

VONDERBANK, K., 1970: Geologie und Fauna der Tertiären Ablagerungen ZentralSpitsbergens. Norsk Polarinstitutt Skrifter Nr. 153.156 pp. 
